\author{
Associate Professor Daniela Livia TRAȘCĂ,PhD \\ E-mail: daniela.trasca@gmail.com \\ Assistant Professor George Marian S,TEFAN,PhD \\ E-mail: stefan.george.m@gmail.com \\ Professor Mirela Ionela ACELEANU,PhD \\ E-mail: aceleanu_mirela@yahoo.com \\ Lecturer Daniela Nicoleta SAHLIAN,PhD \\ E-mail: daniela.sahlian@ cig.ase.ro \\ Associate Professor Georgiana Oana STANIL $\breve{A}$ \\ E-mail: oana.stanila@ase.ro \\ The Bucharest University of Economic Studies \\ Răzvan HOINARU, PhD Researcher \\ E-mail: r.hoinaru@qmul.ac.uk \\ Queen Mary University, London
}

\title{
UNIQUE UNEMPLOYMENT INSURANCE SCHEME IN EURO ZONE. TERMS AND CONDITIONS. IMPACT
}

\begin{abstract}
The insurances for unemployment have an important role in the functioning of labour market and in shocks adjustment. In this article we present a proposal regarding the unemployment insurance scheme in euro area (functionality, eligibility, necessary budget), starting with the relationship between the natural unemployment rate and the effective unemployment rate, on the one hand, and the net replacement rate, on the other hand. In the last section of the article we estimated the reaction of the output gap to the change of unemployment benefits in the countries eligible for European Insurance Scheme using a panel data econometric model with fixed effects. The model was computed for a mixed open economy. Thus, we included as exogenous variables the unemployment rate, the unemployment cash benefits, exports and the gross formation of fixed capital of governmental sector.

Keywords: EMU, Optimum Currency Area, Unemployment insurance, Labour Market, Income Replacement rate.
\end{abstract}

JEL Classification: E24, E40, J65, F45

\section{Introduction}

Unemployment is a current problem which affects European Union, especially the youth. That is why, the concerns for finding solutions, policies and 
Daniela Livia Trașcă, George Marian Ștefan, Mirela Ionela Aceleanu, Daniela Nicoleta Sahlian, Georgiana Oana Stanilă, Răzvan Hoinaru

adequate strategies of labour market increased in the last years, both from the point of view of active and passive measures.

The insurances for unemployment have an important role in the functioning of labour market, and the previous history of workforce occupation influences the model of reintegration on labour market and its performance (Andersen T., 2018). According to Acemoglu and Shimer (1999) this model depends on the aversion to risk. An increase in aversion to risk reduces salaries, unemployment and investments, while the unemployment insurance has the opposite effect, because the insured workers are looking for a job with high wages and high unemployment risk. An economy with workers neutral to risk accomplishes a maximal production without unemployment insurance, but an economy with workers who are facing a risk requires a positive level of unemployment insurance in order to maximize production. Therefore, the moderate unemployment insurance not only improves the split of risks, but also increases production.

Other studies bring in discussion the effects of unemployment benefit schemes on the individual productivity, showing that the benefits of unemployment, especially the unconditional compensations prevent the effort of workers, but the workers hired in an unconditional benefit scheme are more productive than the workers who are under conditional condition. (Blancom et al., 2017).

The weaknesses of institutional architecture in Euro Zone and the many deficiencies of system or economic governance were widely highlighted during the global economic and financial crisis which started in 2007 (Wren-Lewis, 2013; Moro, 2016). In this context, the idea of reforming the Euro Zone was more and more conspicuous (Van Rompuy, H. et al., 2012, Juncker, J. et al., 2015). The crisis has brought to our attention the need for a European unemployment benefit system (EUBS), as a manifestation of solidarity between citizens from different member states, but also as an economic stabilizer in case of future asymmetric shocks (Goodhart, C. and Smith, S. 1993, Allard, C. et al, 2013, Ábrahám, Á. et al, 2018).

Our work analyses the steps taken at European Union level in the elaboration of a unique unemployment benefits scheme, but also brings close-up the conditions of activating the unique scheme in the current context.

In order to identify the impact of unemployment benefits allotted by the member states on the production gap, we made a panel data model with fixed effects, by using the historical data provided by Eurostat and the forecasts from AMECO database for the years 2018 and 2019. The model has in view a mixed open economy. Thus, we included as exogenous variables the unemployment rate, the expenses in cash with unemployed, exports and gross formation of fixed capital of governmental sector. The endogenous variable is the production gap (output gap). 
Unique Unemployment Insurance Scheme in Euro Zone. Terms and Conditions

\section{Review of the scientific literature. Historical stages of elaboration of a unique European unemployment benefit scheme}

The problem of efficiency of automatic stabilizers made the object of many studies and analyses in the Great Recession post-2008 age (Alcidi and Thirion, 2016; Brandolini et al., 2016; Dabrowski, 2015) and in particular, the efficiency of taxation systems and allocation of social benefits was treated so that the shocks on the incomes of individuals are absorbed in a higher proportion, on one hand, and support the aggregate demand and GDP, on the other hand.

The idea of a unique European unemployment benefit scheme has existed since 1975, it made the object of a report, having as authors Marjolin and others. But since then until now we can identify three distinctive periods regarding the approaches of fiscal policy, periods presented in the following paragraphs.

The first period was consumed in the '70s, when the first reports on the Euro zone developed reasonings and concepts such as contagion effects and imbalances of payment balances. Marjolin and others (1975) emphasized then that the economic and monetary unions such as those of USA, Australia, Germany or Canada may exist with very different integration degrees, because of unemployment indemnities and budgetary assistance given to compensate the reduction of incomes. These monetary zones were not only characterized by a central bank and the four fundamental freedoms of Unique Market, but also by a centralized fiscal and social security system (Beblavý, M., Marconi, G., Maselli, I.,2015). The economic reasonings for a joint fiscal policy relate to the contagion effects, imbalances of current accounts and market failures.

In the context of structural problems which generated the persistence of a high unemployment rate, but also the lags between regions (at the level of 1975, between the richest region and the poorest region there was a ratio of 1 to 5), Marjolin report emphasizes the importance of automatic mechanisms which compensate the economic fluctuations. Among these automatic mechanisms there is the increase of transfers which come directly from the central budget or from other centralized financing systems, such as: unemployment benefits, transfers by regional policy or the budgetary assistance which compensates the reduction of regional fiscal incomes by decreasing the contributions to these systems.

As for these issues, the report emphasizes that an economic and monetary union involves both a joint monetary policy and a joint economic and social policy regarding the distribution of authority. In its final stage, the Community has to fulfil by its budget the three traditional functions of any public authority: the allocation function, the stabilization function and the (re)distribution function.

In order to overcome the imbalances of Community member states, the group who drew up the Marjolin report considered that the introduction of a community system of unemployment benefits would be an efficient solution. For creation of 
Daniela Livia Trașcă, George Marian Ștefan, Mirela Ionela Aceleanu, Daniela Nicoleta Sahlian, Georgiana Oana Stanilă, Răzvan Hoinaru

this system, the member states of Community must prove first of all that they are solidary, and then the harmonization of national systems should take place.

Two years later, in 1977, a new report was published, having as objective the analysis of the role in the future of the public finances at Community level, in the general context of European economic integration. The Commission who drew up this report had as president Donald MacDougall (1977). The MacDougall report proposes the creation of a system of cyclical subsidies (cyclical grants) for the local and central authorities. This is a financial redistribution system based on the granting of subsidies, under different constraints such as: specific conditions which aim at increasing the economic capacity, economic criteria connected with the cyclical and structural relative economic situations of regions, but also conditions regarding the performances of economic policy, in those situations when the member states hold control.

The second period started at the end of ' 80 s, when the Euro Zone became a concrete project and includes studies which suggest different variants for the stabilization mechanisms for Euro Zone or for European Union. Although the reasonings were revised, the debates did not lead to the creation of a fiscal capacity of the Euro Zone, even if unlike the '70s, unemployment had become a prominent problem everywhere, and the fiscal policy was recognized as an instrument for management of demand. The idea of a conditional regional policy was resumed in this stage by the report of Padoa-Schioppa and others, in 1987. This report suggests that the less developed regions or those which cross a decline period should be supported in two ways: by subsidizing the interest rate at the loans given to the private sector by the European Investment Bank or by other financial institutions or by granting subsidies supported by structural funds to the regions in difficulty. The transfer sunder the form of subsidization of interest rate will be conditioned by the quality of programmes by which the private sector receives support, while the transfers under the form of subsidies supported by structural funds will be conditioned by the implementation of a strategy which contains structural policies and reforms.

In another order of ideas, in this stage alternatives are proposed such as the regional policy, having as possible mechanisms the cyclical and conditional grants. The report of Padoa-Schioppa of 1987 involves the budget of European Community as constant around 1\% of European GDP. On the other hand, Emerson and others (1990) suggest that the market forces are able to correct the imbalances generated by the unique currency without the need for a joint substantial macroeconomic policy.

The third stage started with the Great Recession (2008-2009) and continues even today. Most of the studies appeared after the launch of Euro currency, aim at redistributive side and especially the action of income stabilization after different shocks. For the estimation of size of automatic stabilization of incomes of 
Unique Unemployment Insurance Scheme in Euro Zone. Terms and Conditions

individuals, in the specialized literature different methods were used. One of them is normalized tax change and was used by Auerbach and Feenberg (2000). Starting from this method, Dolls et al. (2010) defined the income stabilization coefficient, which shows in what way the changes of incomes obtained on the market (market income) lead to changes of available income by the change of payments level with taxes on personal income.

Dolls et al. (2010) claim that the countries of South-Eastern Europe are characterized by rather low automatic stabilizers and this has several explanations. A first reason can be that the countries with lower income per capita tend to have smaller public sectors. Also, we can add that the fiscal systems are characterised by a lower degree of progress, sometimes as a result of the desire to acquire an extra attractiveness for investors. They claim that the countries with stronger automatic stabilizers were relatively more resistant during the crisis from the perspective of production volatility, while the countries with poor automatic stabilizers recorded major economic decreases, unemployment increase and an exacerbation of social problems against the background of reduction of individuals' incomes.

In the last few years, against the background of high unemployment rates in countries such as Greece, Spain, Portugal or Italy, in Euro zone there was discussed the creation of a European unemployment insurance scheme which completes or even replaces the national unemployment benefit systems. This is considered as a much feasible variant compared to the alternative of a unified system of fiscal transfers at Euro Zone level. The funds collected in this scheme should be oriented towards the countries which have a high unemployment rate with or without conditions in order to support the available incomes and stimulate the internal demand (Dullien, 2013). The method by which these transfers could be made was widely discussed in the specialized literature and several issues were raised: if there should be transfers for a period equal to the number of years in which a certain country from Euro zone is with unemployment rate above a certain "critical threshold" (for example, an unemployment rate higher by 1 p.p. or more over a set threshold of $7 \%$ or compared to the estimated level of natural unemployment rate), if these allocations should be made accompanied by conditions (i.e. structural reforms) which are imposed (i.e. condition of allocation of certain amounts from the national budget for activation policies).

The unemployment benefits represent anticyclical budgetary costs which act as far as the unemployment grows and the economy is facing major difficulties. They are also a fast instrument by which they can support the incomes of individuals during recession and reduce its social costs (represent a safety net for a large part of population). At the same time, by their multiplication effects they support consumption and automatically contribute to the increase of aggregate demand.

Many studies performed by Dullien (2013), Italianer and Vanheukelen (1993), Beblavý and Maselli (2014), Beblavý et al. (2015, 2017) - suggest several methods by which we define the triggering method and the context in which they resort to the unemployment benefit scheme at European level. 
Daniela Livia Trașcă, George Marian Ștefan, Mirela Ionela Aceleanu, Daniela Nicoleta Sahlian, Georgiana Oana Stanilă, Răzvan Hoinaru

Table 1. Triggering methods proposed for the European Unemployment Insurance Scheme

\begin{tabular}{|c|c|}
\hline Authors & Triggering methods \\
\hline $\begin{array}{c}\text { Dullien } \\
\text { (2013) }\end{array}$ & $\begin{array}{l}\text { An unemployment rate above } 7 \% \text { and an increase by } \\
1 \text { p.p. in the last year } \\
\text { An unemployment rate above } 5 \% \text { and an increase by } 1 \text { p.p. } \\
\text { in the last year } \\
\text { An unemployment rate above } 7 \% \text { and an increase above } \\
15 \% \text { in the last year }\end{array}$ \\
\hline $\begin{array}{l}\text { Italianer and } \\
\text { Vanheukelen } \\
\quad(1993)\end{array}$ & $\begin{array}{l}\text { The increase in unemployment rate in the last year is } \\
\text { positive and is higher than the average increase in the } \\
\text { other EU member states }\end{array}$ \\
\hline $\begin{array}{l}\text { Beblavý and } \\
\text { Maselli } \\
\text { (2014) }\end{array}$ & $\begin{array}{l}\text { The difference between the unemployment rate and } \\
\text { NAIRU rate (unemployment rate which does not } \\
\text { accelerate the inflation rate) exceeds } 2 \text { p.p. }\end{array}$ \\
\hline $\begin{array}{l}\text { Beblavý et } \\
\text { al. (2015) }\end{array}$ & $\begin{array}{l}\text { The short-term unemployment rate exceeds its average } \\
\text { value from the last } 10 \text { years and by } 10 \% \text { its standard } \\
\text { deviation from the last } 10 \text { years. } \\
\text { The short-term unemployment rate exceeds its average } \\
\text { value from the last } 10 \text { years and its standard deviation } \\
\text { from the last } 10 \text { years. } \\
\text { The short-term unemployment rate exceeds its average } \\
\text { value from the last } 10 \text { years and by } 200 \% \text { its standard } \\
\text { deviation from the last } 10 \text { years. }\end{array}$ \\
\hline
\end{tabular}

In the following sections we presented our proposal regarding the unemployment benefit scheme. At the same time, we emphasized the importance of the scheme for the entire eurozone and for the eligible countries at this moment.

The method of operation, financing sources and triggering method for eligible states

In Euro zone, as the data of European Commission show - AMECO, we can notice the strong impact of economic crisis on the labour market. The economic crisis, along with the decrease of consumption and investments and because of implementation of austerity plans in different member states (especially in PIIGS) made the unemployment rate increase above its natural level.

Only at the beginning of year 2018 the unemployment rate seems to be at its natural level on the background of gradual closure of production gap, the relaunch of consumption and investments and comeback of economic growth 


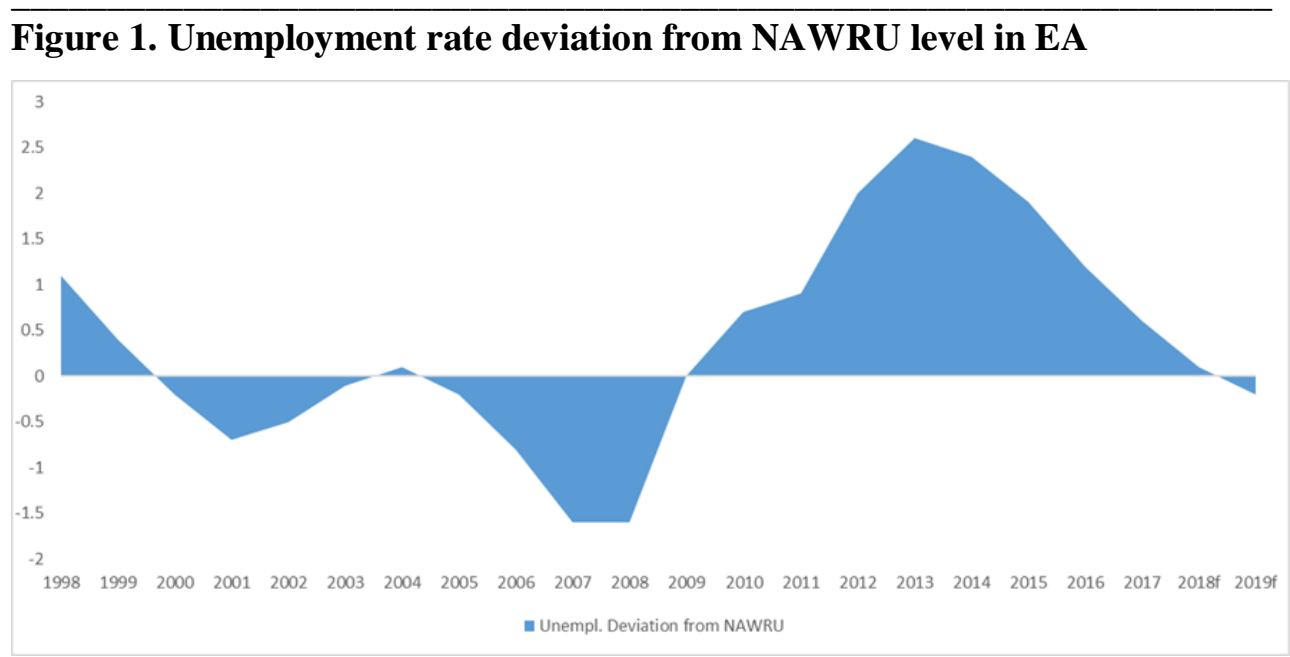

Source: authors' calculations based on AMECO data

For the quantification of costs which should be covered by the unique unemployment scheme at Euro Area level several estimates were made, since the coming into force of Maastricht Treaty. Thus, the first estimates were made by Italianer and Vanheukelen (1993), who obtained an annual costs level of $0.5 \%$ of EU GDP. This result was obtained by multiplying the average number of unemployed in EU by the average wages in EU and later by a replacement rate of $70 \%$ of these wages.

Other studies which make estimates regarding the size of a European unemployment benefit scheme start from a given period of granting these benefits, a replacement rate determined by the size of benefits compared to a reference salary and a given coverage rate of individuals in this scheme. Dullien (2013), for example, establishes a maximal period of granting benefits of 12 months and a replacement rate of $40 \%$ or $50 \%$ (the same as in Dolls et al. (2014), Jara and Sutherland (2014), (Beblanyy et al. (2015)).

Beblavý and Maselli (2014) estimate a hypothetical cost of European unemployment benefit scheme during the period 1999-2012 of 0.07\% of EU GDP, if this was activated in the most restrictive conditions. Similarly, Dullien (2007, 2013 ), in different scenarios, estimates annual costs which vary from $0.75 \%$ to $0.85 \%$ of GDP of Euro Zone or between $0.3 \%$ and $0.6 \%$ of EU GDP.

On the other hand, the study performed by Dolls et al. (2014) proposes a European scheme for unemployment insurances at Euro Area level which would have a cost of about 50 billion euro per year (respectively $0.6 \%$ of GDP). A higher value for the budget of this scheme is proposed by Pisani-Ferri et al. (2013), which if it covered all the costs with unemployment benefits of member states, it would be $1.8 \%$ of GDP of Euro Zone (based on the national values of the period 2002-2010). 
Daniela Livia Trașcă, George Marian Ștefan, Mirela Ionela Aceleanu, Daniela Nicoleta Sahlian, Georgiana Oana Stanilă, Răzvan Hoinaru

However, we consider that this value is extremely generous compared to the estimates of the other studies, where in general the budget of such a scheme is between $0.3 \%$ of GDP and $0.85 \%$ of the GDP of member states.

In our vision, the triggering method concerns the relationship between the natural unemployment rate and the effective unemployment rate. In other words, a state becomes eligible to benefit from funds from the unemployment benefit scheme if it has an unemployment rate above the average unemployment rate of the last three economic cycles, in this case starting from the annual average unemployment rate from the period 2000-2017.

We also followed what the annual budgetary impact would be if the income replacement rate increased to $80 \%$ and to $100 \%$ of the salary income earned previously by a single individual who earned wages equal to the gross national average wages.

At the end of the year 2017, against the background of comeback of economic growth which stimulated the demand of workforce, we can notice a decrease of unemployment rate in all the states of European Union compared to the previous year, in some of them even with values of above 2 p.p. (Greece, Spain, Croatia or Portugal), but many states continue to record unemployment rates above their natural level.

Based on the data regarding unemployment rate and natural unemployment rate we notice that not less than nine member states (Austria, France, Greece, Spain, Italy, Portugal, Cyprus, Finland and Luxembourg) had an unemployment rate above its natural level in the analysed period and therefore, they would be eligible to receive transfers from the European Unemployment Scheme - EUS. The latter will contribute (partially or totally) to a net income replacement rate of $80 \%$ (above the actual level of most of the states) and to $100 \%$ from the income.

Also, starting from the actual net income replacement rates (calculated for single individuals who earned previously $100 \%$ of the average national wages) we calculated how much EUS should contribute in addition to the national unemployment budget of each country, so that the replacement rate increases to $80 \%$ and $100 \%$, to support the comeback of internal demand and therefore, the increase of Gross Domestic Product of each country. In the figure below, we can notice a relatively important difference between the selected member states regarding the net income replacement rate. For instance, we can see that in Greece, by the unemployment schemes, the transfers provided by the national government cover a level of almost $29 \%$ of the previous income of the individual, while they are much higher in Portugal $(75 \%)$ or in Luxembourg $(85,6 \%)$. Relatively close levels are in Spain, Austria (55\% both), and higher rates are found in France $(68 \%)$, Finland $(64,9 \%)$ and Italy $(64,25 \%)$. For Cyprus, the net income replacement rate was not available 
Unique Unemployment Insurance Scheme in Euro Zone. Terms and Conditions

Figure 2. Net replacement rate of income in selected member states (2016)

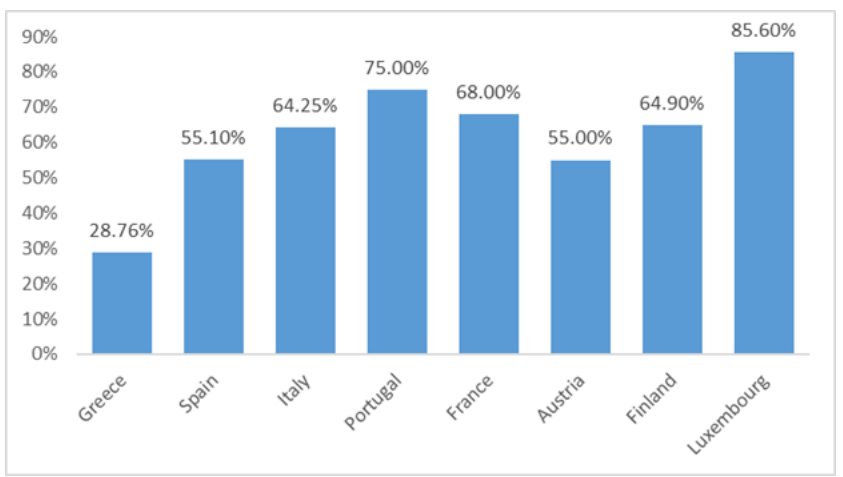

Source: European Commission, Tax and Benefits Database

Thus, we analysed two scenarios of application of the EUS:

(i) The first scenario aims at an increase of $80 \%$ of net replacement rate, in this case Luxembourg goes out of impact calculation, with a level of over $85 \%$ of net replacement rate.

(ii) The second scenario involves an increase of $100 \%$ of net replacement rate of income, in this case we consider the state Luxembourg.

Both scenarios were analysed: (a) the case when the common budget (EUS) covers the entire value of additional unemployment benefit which would be received by individuals and (b) whether it was equally split (50/50) between the national budget (NUS) and the unique community budget (EUS). In Table 2 we present the results regarding the necessary annual payments with unemployment benefits in the eligible states.

Table 2: Budgetary impact of EUS for selected countries (annually values)

\begin{tabular}{|c|l|l|l|}
\hline & \multicolumn{1}{|c|}{ First Scenario } & \multicolumn{2}{|c|}{ Second Scenario } \\
\cline { 2 - 4 } & $100 \%$ covered by EUS & $50 \%$ covered by EUS & 50\% covered by NUS \\
\hline $\begin{array}{c}80 \% \text { net } \\
\text { replacement } \\
\text { ratio }\end{array}$ & $\begin{array}{l}52 \text { billion EUR } \\
0.46 \% \text { of EA19 GDP }\end{array}$ & $\begin{array}{l}26 \text { billion EUR } \\
0.23 \% \text { of EA19 GDP }\end{array}$ & $\begin{array}{l}26 \text { billion EUR from } \\
\text { national budget of } \\
\text { selected countries }\end{array}$ \\
\hline $\begin{array}{c}100 \% \text { net } \\
\text { replacement } \\
\text { ratio }\end{array}$ & 65 billion EUR & $\begin{array}{l}32,5 \text { billion EUR } \\
0.29 \% \text { of EA19 GDP }\end{array}$ & $\begin{array}{l}32,5 \text { billion EUR from } \\
\text { national budget of } \\
\text { selected countries }\end{array}$ \\
\hline
\end{tabular}

Source: authors' calculation based on Eurostat and European Commission, Tax and Benefits Database

If we opt for the variant when $50 \%$ of the amount allotted as unemployment benefit is taken from the national budget and we increase the net income replacement rate to $80 \%$ or to $100 \%$, our results show that the national budget 
Daniela Livia Trașcă, George Marian Ștefan, Mirela Ionela Aceleanu, Daniela Nicoleta Sahlian, Georgiana Oana Stanilă, Răzvan Hoinaru

(especially the payments in cash) should be significantly increased corresponding to the initial level of net income replacement rate.

For instance, we notice that the biggest increases of the amounts allotted from the national budget for unemployment should be made in Greece, Spain and Finland. In Greece it should double, from $1 \%$ to $2 \%$ of GDP, in Spain increase from $2 \%$ to $2.6 \%$ of GDP and in Finland the increase should be made from $2.4 \%$ to $2.9 \%$ of GDP. The other states are presented in the figure below.

Figure 3. Necessary extra-funds for $80 \%$ scenario

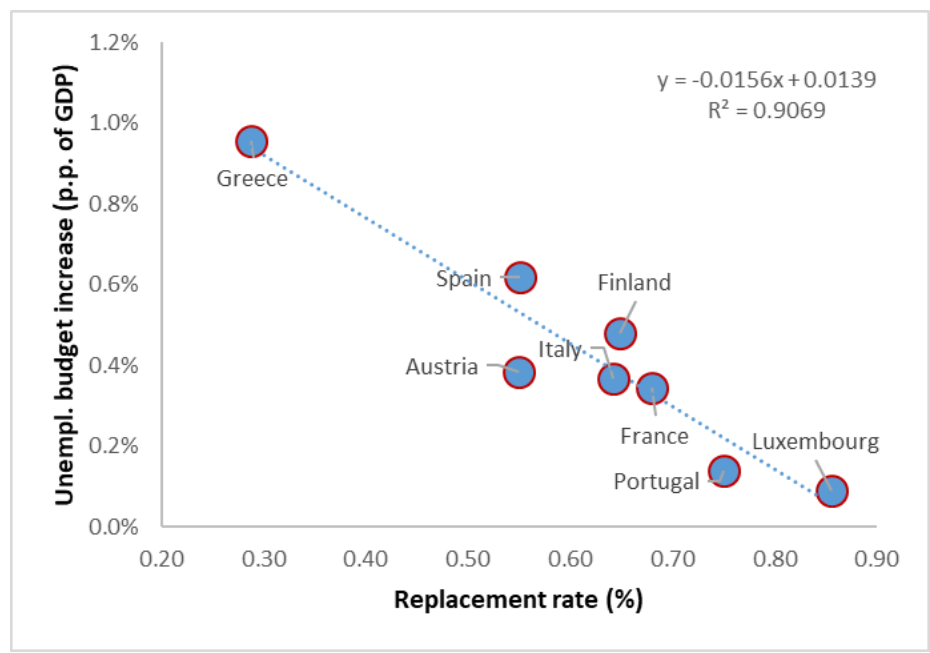

Figure 4. Adjusted national unemployment budget for $80 \%$ scenario

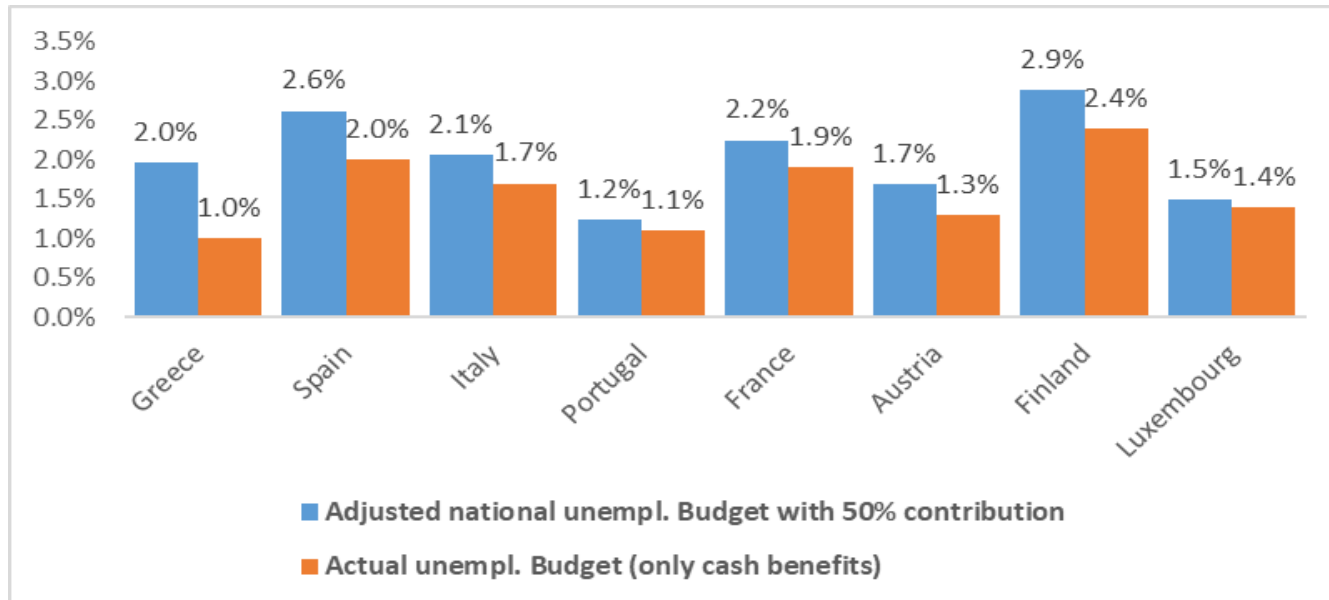

Source: authors' calculation based on Eurostat and European Commission, Tax and Benefits Database 
Figure 5. Necessary extra-funds for $100 \%$ scenario



Figure 6. Adjusted national unemployment budget for $100 \%$ scenario



Source: authors' calculation based on Eurostat and European Commission, Tax and Benefits Database

Estimation of the impact of unemployment benefits in Euro Area on the output gap

From a theoretical point of view, an increase of unemployment benefits allotted by the member states should contribute to the increase of available income, should support the private consumption and thus support the economic growth and the comeback of GDP to its potential level.

Based on historical data Eurostat and forecasts from the database AMECO for the years 2018 and 2019, we made a panel type econometric model with fixed effects 
Daniela Livia Trașcă, George Marian Ștefan, Mirela Ionela Aceleanu, Daniela Nicoleta Sahlian, Georgiana Oana Stanilă, Răzvan Hoinaru

by which we estimated the way in which the production gap reacted to the change of unemployment costs in the countries selected in the previous section. The model has in view a mixed open economy. All variables were taken in the first difference, being stationary. The variable regarding the payments with unemployment benefits was taken with a lag of one year, considering that an additional period is necessary for the effects of additional income received by individuals to manifest themselves on consumption.

OUTPUTGAP $_{\mathrm{it}}=\mathbf{C}+\boldsymbol{\beta} *$ UNEMPL $_{\mathrm{it}}+\alpha^{*}$ UNEMPLCASH $_{\mathrm{it}}(-1)+\gamma^{*}$ FBCF $_{\mathrm{it}}+$ $\delta^{*} \mathbf{E X P}_{\mathrm{it}}+\boldsymbol{\varepsilon}_{\mathrm{it}}$

Where:

OUTPUTGAP $=$ the difference between the actual level of GDP and its estimated potential level.

UNEMPL = unemployment rate

UNEMPLCASH = payments in cash with unemployment benefits expressed as weight in GDP

$\mathrm{FBCF}=$ gross formation of fixed capital of governmental sector expressed as weight in GDP

$\mathrm{EXP}=$ exports expressed as weight in GDP

$\mathrm{C}=$ constant of panel model;

$\beta, \alpha, \gamma, \delta=$ elasticity coefficients of exogenous variables

$\boldsymbol{\varepsilon}=$ error term

The results of the model were as follows:

$\mathrm{D}($ OUTPUTGAP $)=-0.147-\mathbf{0 . 9 4} * \mathrm{D}($ UNEMPL $)+\mathbf{0 . 6 1} * \mathrm{D}($ UNEMPLCASH $(-1))+$ $0.34 * \mathrm{D}(\mathrm{FBCF})+\mathbf{0 . 2 3} * \mathrm{D}(\mathrm{EXP})$

As we can notice about the values of coefficients obtained by using the software Eviews 7, for the analysed period, in the 9 countries selected in panel (Austria, France, Greece, Spain, Italy, Portugal, Cyprus, Finland and Luxembourg), the coefficients obtained for the four exogenous variables are in accordance with economic theory. Also, the explanatory power of variables included in the model, expressed by the value of R-squared is over $60 \%$, which involves that $60 \%$ of the change of endogenous variable (production gap) are explained by the change of exogenous variables (unemployment rate, gross formation of fixed capital of government, payments in cash with unemployment benefits, exports).

The model shows that during the period 1998-2018 there is a negative relationship between unemployment rate and the output gap and positive relations between the payments with unemployment, the gross formation of fixed capital and exports. Thus, the increase of unemployment rate leads to the reduction of output gap, while the increase of payments with unemployment benefits, governmental investments and exports - by increase of available income and respectively aggregate demand - leads to the increase of production gap. 
Unique Unemployment Insurance Scheme in Euro Zone. Terms and Conditions

Out of the four exogenous variables, it seems that unemployment rate has the largest impact on outputgap - an increase by one percentage point of unemployment rate leads to a change in opposite direction of production gap with about the same magnitude (0.94 p.p.).

\begin{tabular}{|c|c|c|c|c|}
\hline $\begin{array}{l}\text { Dependent Variable: D( } \\
\text { Method: Panel Least Sq } \\
\text { Date: 09/23/18 Time: } 1 \\
\text { Sample (adjusted): } 199 \\
\text { Periods included: } 21 \\
\text { Cross-sections include } \\
\text { Total panel (unbalanced }\end{array}$ & $\begin{array}{l}\text { JTPUTGAP) } \\
\text { ares } \\
11 \\
2018 \\
9 \\
\text { observation }\end{array}$ & 165 & & \\
\hline Variable & Coefficient & Std. Error & t-Statistic & Prob. \\
\hline $\mathrm{C}$ & -0.147170 & 0.104726 & -1.405283 & 0.1620 \\
\hline D(UNEMPL) & -0.939193 & 0.076709 & -12.24366 & 0.0000 \\
\hline D(UNEMPLCASH(-1)) & 0.612644 & 0.544861 & 1.124405 & 0.2626 \\
\hline $\mathrm{D}(\mathrm{FBCF})$ & 0.344959 & 0.228418 & 1.510210 & 0.1331 \\
\hline$D(E X P)$ & 0.232105 & 0.028049 & 8.274905 & 0.0000 \\
\hline & Effects Sp & cification & & \\
\hline Cross-section fixed (dur & my variables & & & \\
\hline R-squared & 0.628133 & Mean depen & ent var & -0.026788 \\
\hline Adjusted R-squared & 0.598775 & S.D. depend & nt var & 2.028214 \\
\hline S.E. of regression & 1.284717 & Akaike info $c$ & terion & 3.414465 \\
\hline Sum squared resid & 250.8757 & Schwarz crite & ion & 3.659176 \\
\hline Log likelihood & -268.6934 & Hannan-Qui & n criter. & 3.513802 \\
\hline F-statistic & 21.39573 & Durbin-Wats & n stat & 2.256104 \\
\hline Prob(F-statistic) & 0.000000 & & & \\
\hline
\end{tabular}

Source: authors' calculation based on Eviews 7 software

On the other hand, between the other variables selected (unemployment benefits, the gross formation of fixed capital of government, exports) and production gap there is a direct, positive relationship, even if the statistical significance degree (reflected by the probability of accepting/rejecting the null hypothesis) in case of unemployment benefits and gross formation of fixed capital is much more reduced.

In case of payments with unemployment we notice that an increase of them by $1 \%$ of GDP in the previous period leads now to an increase of production gap by increasing the aggregate demand by 0.61 percentage points, while at increase by 1 p.p of GDP of gross formation of fixed capital of government - respectively, an increase in investments - there is an increase of production gap by 0.34 percentage points. Relatively close to this coefficient there is the contribution of exports. According to the estimated coefficients, an increase of exports by 1 p.p. of GDP contributes to the increase of production gap by 0.23 p.p. 
Daniela Livia Trașcă, George Marian Ștefan, Mirela Ionela Aceleanu, Daniela Nicoleta Sahlian, Georgiana Oana Stanilă, Răzvan Hoinaru

\section{Conclusions}

The analysis of efficiency of taxation systems and allocation of social benefits made the object of many studies and analyses, especially as reaction to the crisis of 2007-2008. The persistence of high unemployment rates in countries such as Greece, Spain, Portugal or Italy brought to the attention of European leaders the necessity to create at Euro Zone level a European unemployment scheme which completes or replaces the national social aid systems.

There are many opinions around this scheme either related to the method of funding the fund, or the period for which these social transfers are granted or the eligible states or the triggering method.

In our opinion, the activation of unique scheme should consider the relationship between the natural unemployment rate and the effective unemployment rate. Thus, a state becomes eligible when it has an unemployment rate above the average unemployment rate of the last three economic cycles.

Our analysis has in view the period 2000-2017. Based on the data regarding the unemployment rate and the natural unemployment rate, we identified nine member states, respectively Austria, France, Greece, Spain, Italy, Portugal, Cyprus, Finland and Luxembourg, which had in the analysed period an unemployment rate above its natural level and therefore, would be eligible to receive transfers from the European Unemployment Scheme - EUS.

We also determined, based on net income replacement rates, how much they should contribute in excess to the unemployment budget of each country. While in Greece the transfers provided by the national government cover a level of almost $29 \%$ of the previous income of the individual, in countries such as Portugal or Luxembourg, the level is much higher.

In this context, we assumed two scenarios:

- The first scenario aims at an increase by $80 \%$ of the net replacement rate, in which case Luxembourg exits the calculation of impact, having a level of over $85 \%$ of net replacement rate;

- The second scenario involves an increase by $100 \%$ of net income replacement rate, in this case we consider the state Luxembourg.

If we opt for the variant when $50 \%$ of the amount allotted as unemployment benefit is taken from the national budget and we increase the net income replacement rate to $80 \%$ or to $100 \%$, our results show that the national budget (especially the payments in cash) should be significantly increased corresponding to the initial level of net income replacement rate. Thus, the biggest increases of the amounts allotted from the national budget for unemployment should be made in Greece, Spain and Finland. In Greece it should double from $1 \%$ to $2 \%$ of GDP, in Spain from 2\% to 2.6\% of GDP, and in Finland the increase should be made from $2.4 \%$ to $2.9 \%$ of GDP. 
Unique Unemployment Insurance Scheme in Euro Zone. Terms and Conditions

The values of coefficients obtained by using the software Eviews 7, for the analysed period, in the 9 countries selected in panel (Austria, France, Greece, Spain, Italy, Portugal, Cyprus, Finland and Luxembourg), are in accordance with economic theory. the explanatory power of variables included in the model, expressed by the value of R-squared is over $60 \%$, which involves that $60 \%$ of the change of endogenous variable (production gap) are explained by the change of exogenous variables (unemployment rate, gross formation of fixed capital of government, payments in cash with unemployment benefits, exports).

Out of the four exogenous variables, it seems that unemployment rate has the largest impact on production gap - an increase by one percentage point of unemployment rate leads to a change in opposite direction of production gap with about the same magnitude (0.94 p.p.).

On the other hand, between the other variables selected (unemployment benefits, the gross formation of fixed capital of government, exports) and production gap there is a direct, positive relationship, even if the statistical significance degree (reflected by the probability of accepting/rejecting the null hypothesis) in case of unemployment benefits and gross formation of fixed capital is much more reduced.

In case of payments with unemployment we notice that an increase of them by $1 \%$ of GDP in the previous period leads now to an increase of production gap by increasing the aggregate demand by 0.61 percentage points, while at increase by 1 p.p of GDP of gross formation of fixed capital of government - respectively, an increase in investments - there is an increase of production gap by 0.34 percentage points. Relatively close to this coefficient there is the contribution of exports. According to the estimated coefficients, an increase of exports by 1 p.p. of GDP contributes to the increase of production gap by 0.23 p.p.

Although the financial support of a unique unemployment benefit scheme involves additional financial efforts from the member states, the analysis performed by us supports this idea, especially if the unemployment rate and unemployment cash benefits have the biggest impact on the production gap.

\section{REFERENCES}

[1] Céline Allard, Petya Koeva Brooks, John C. Bluedorn, Fabian Bornhorst, Katharine Christopherson, Franziska Ohnsorge, Tigran Poghosyan (2013), Toward a Fiscal Union for the Euro Area; IMF Staff Discussion Note, No.13/09, Washington, D.C.;

[2]Alcidi, C., Thirion, G. (2016), Assessing the Effect of Shocks in the Euro Area's Shock Absorption Capacity-Risk-Sharing, Consumption Smoothing and Fiscal Policies; CEPS Special Report No. 146; CEPS, Brussels, March 2016; [3]Ábrahám, Á., Brogueira de Sousa, J., Marimon, R. and Mayr, L. (2018), On the Design of an European Unemployment Insurance System; 
Daniela Livia Trașcă, George Marian Ștefan, Mirela Ionela Aceleanu,

Daniela Nicoleta Sahlian, Georgiana Oana Stanilă, Răzvan Hoinaru

[4]Auerbach, A. and Feenberg, D. (2000), The Significance of Federal Taxes as Automatic Stabilizers; Journal of Economic Perspectives 14: 37-56;

[5]Beblavý, M. and I. Maselli (2014), An Unemployment Insurance Scheme for the Euro Area: A simulation Exercise of two Options; CEPS Special Report No. 98, CEPS, Brussels, December;

[6]Beblavý, M., Marconi, G., Maselli, I. (2015), An European Unemployment Benefit Scheme-The Rationale and the Challenges ahead; CEPS Special Report No.119, CEPS, Brussels;

[7]Beblavy, M., Lenaerts, K., Maselli, I. (2017), The (Future) European Unemployment Insurance and Its Role as an Automatic Stabiliser, Euro and the Crisis: Perspectives for the Eurozone as a Monetary and Budgetary Union; [8]Blancom, M., Dalton, P., Vargas, J. (2017), Does the Unemployment Benefit Institution Affect the Productivity of Workers? Evidence from the Field; Management Science, Volume: 63, Issue: 11,pp 3691-3707;

[9]Brandolini, A., Carta, F. and D'Amuri, F. (2016), A Feasible Unemployment Based Shock Absorber for the Euro Area. JCMS: Journal of Common Market Studies, 54(5), pp.1123-1141;

[10]Dabrowski, M. (2015), Monetary Union and Fiscal and Macroeconomic Governance; Discussion Paper 013, DG for Financial and Economic Affairs, European Commission, Brussels;

[11]Dolls, M., C. Fuest, D. Neumann and A. Peichl (2014), An Unemployment Insurance Scheme for the Euro Area: Evidence at the Micro Level; Paper prepared for the seminar Economic shock absorbers for the Eurozone-Deepening the debate on automatic stabilizers, Brussels, June;

[12]Dolls, Mathias; Fuest, Clemens; Peichl, Andreas (2010), Automatic Stabilization and Discretionary Fiscal Policy in the Financial Crisis; IZA Journal of Labor Policy, Springer, Heidelberg, Vol. 1, pp. 1-19;

[13]Dullien, S. (2007), Improving Economic Stability in Europe. What the Euro Area Can Learn from the United States' Unemployment Insurance; Working Paper FG 1; German Institute for International and Security Affairs (SWP), Berlin; [14]Goodhart, C., Smith, S. (1993), Stabilization, European Economy; Reports and Studies, No.5.;

[15]Juncker, J. (2015), Completing Europe's Economic and Monetary Union. European Commission, Brussels;

[16]Moro, D. (2016), For a Federal European Unemployment Insurance

Scheme; Reflection paper; Union of European Federalists, Brussels, March; [17] Van Rompuy, H. et al. (2012), Towards a Genuine Economic and Monetary Union; Report of the President of the European Council, Brussels, 5 December; [18]Wren-Lewis, S. (2013), Macroeconomic Stabilisation in the Eurozone: Lessons from Failure; Global Policy, 4(1). 